
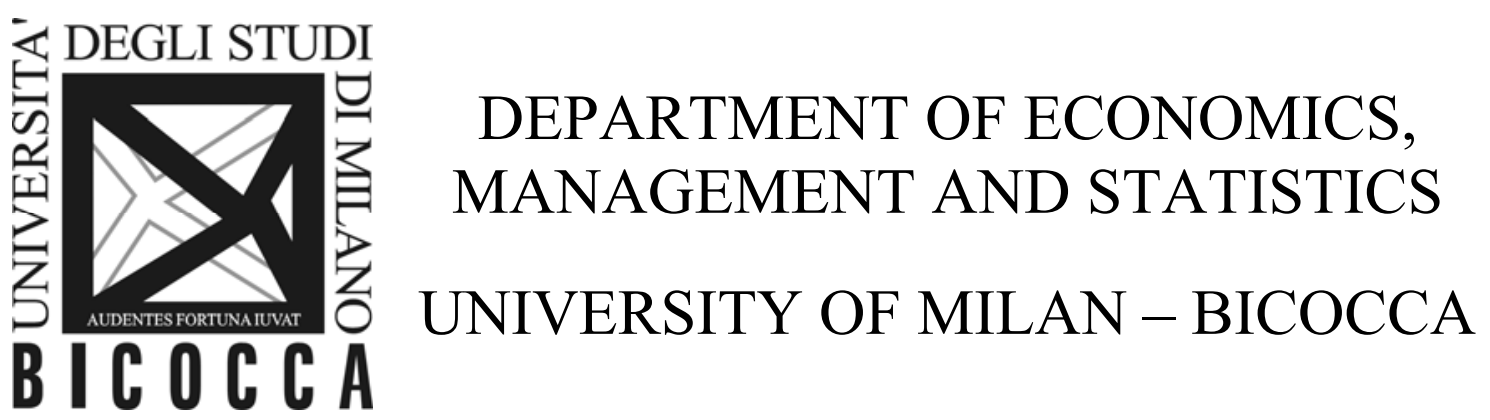

DEMS WORKING PAPER SERIES

Communication and performance in Bank-Fund joint participation

Silvia Marchesi

No. 319 - November 2015

Dipartimento di Economia, Metodi Quantitativi e Strategie di Impresa Università degli Studi di Milano - Bicocca

http://dems.unimib.it/ 


\title{
Communication and performance in Bank-Fund joint participation
}

\author{
Silvia Marchesi* \\ University of Milano Bicocca and Centro Luca d'Agliano
}

November 2015

\begin{abstract}
In this paper I relate Bank-Fund's performance to their willingness (or ability) to communicate. I find evidence that a Bank-Fund simultaneous loan is associated to an increase in economic growth and that such effect is diminished by factors preventing full communication, such as the degree of Bank-Fund competition and the salience of asymmetric information. Politically motivated loans seem -at least to some extentstimulate more IMF-WB interaction which turns out to be associated to higher economic growth.
\end{abstract}

Keywords: IMF and WB conditionality, coordination, communication JEL Classification: D83, F33, N2.

*I thank Axel Dreher, Martin Gassebner, Rune Hagen, Christopher Kilby, Stephen Knack, Audrey Menard and Randall Stone for useful comment and suggestions. A preliminary version of this paper was presented at the Political Economy of International Organizations (PEIO) Annual Meeting (Berlin, 2015) and at the BBQ Conference (Heidelberg, 2014). E-mail address: silvia.marchesi@unimib.it. 
"While everyone agrees that coordination is necessary, nobody wants to be the one that is coordinated," Joachim Koops (director of the Global Governance Institute, a Brussels-based think-tank, The Economist June 1st 2013)

\section{Introduction}

The International Monetary Fund (IMF) and the World Bank (WB) were originally created as two independent institutions with complementary tasks and different methods of intervention, within the framework of the Bretton Woods agreement (1944). Over the years, however, their mandates have expanded in response to the changing realities of the global economy and the degree of overlap between the two has increased, leading to more room for both conflict and cooperation.

Official reports, that have tried to identify guidelines aimed at enhancing cooperation between the Bank and the Fund, have almost unanimously agreed that "information sharing" is the area which still needs to be greatly improved (e.g., IMF 2007, 2010; IMF and World Bank 2001, 2007). This comes as no surprise since successful cooperation does require effective transmission of information (communication) whenever informational asymmetries exist. Thus, investigating what factors influence the quality and the extent of communication between the Bank and the Fund has now become particularly relevant. Little theoretical and empirical analyses, however, exist about what circumstances may inhibit or encourage Bank-Fund and communication. More generally, despite a vast literature considering the individual impact of the IMF and the WB on recipient countries' economic growth and development, little is known about the effects of their simultaneous presence in recipient countries. ${ }^{1}$

This paper contributes to fill this gap by empirically relating Bank-Fund's performance to measures of their willingness (or ability) to communicate. As the reform agenda has deepened to include institutional and social reforms, the collection of specialized information by the Fund and the Bank has increasingly consisted in acquiring country-specific inputs (or local knowledge), which are mainly made up of unverifiable information (soft information). ${ }^{2}$ In this context, the existence of incentives conflicts between the Bank and the Fund might hinder credible information transmission, as shown in the Crawford and Sobel (1982) seminal paper on strategic information transmission. ${ }^{3}$

\footnotetext{
${ }^{1}$ See Fabricious (2007) and Marchesi and Sirtori (2011).

${ }^{2}$ For more details on the importance of context-specific knowledge for reforms design see, among others, Dixit (2009), Easterly (2006, 2008, 2013), Rajan (2008) and Marchesi et al. (2011).

${ }^{3}$ In particular, Marchesi and Sabani (2014) present a theoretical model which, analyzing the sources of the expected loss in the overall performance of the two institutions, finds that -given the Bank-Fund strong
} 
Even though my analysis could be easily applied to the interaction of many types of international organizations (think for example to the interaction within the "Troika"), in this paper I have chosen to focus only on the IMF-WB interaction for mainly two reasons. Firstly, since the ' 80 s the degree of overlap between the two institutions has been steadily increasing making their communication increasingly important. The second reason is that data availability makes relatively easier to test some of the empirical predictions of the theoretical model, while it would be much more difficult to find comparably data in the case of other organizations.

As a measure of Bank-Fund's performance I take the relationship between a Bank-Fund simultaneous loan and a recipient country's growth and, similarly to Marchesi and Sirtori (2011), I find evidence that Bank-Fund simultaneous loan is positively correlated with growth. However, while in Marchesi and Sirtori (2011), IMF-WB simultaneous involvement in a recipient country was taken as a "black box" with no effort to investigate possible channels of their simultaneous action, the contribute of this paper is to consider whether the IMF and the WB ability or willingness to communicate could be one of these channels. ${ }^{4}$

More specifically, I find that such positive link is increased by factors enhancing communication, such as the degree of Bank-Fund competition and the salience of their private information. Politically motivated loans -at least to some extent- seem to stimulate more IMF-WB interaction which turns out to be associated to higher economic growth.

The paper is organized as follows. Section 2 contains some institutional information regarding the IMF and the WB while section 3 describes the main variables of the empirical analysis. Sections 4 and 5 show the empirical model and results and, finally, section 6 summarizes and concludes.

\section{The IMF and the World Bank: synergies and conflict}

The World Bank and the IMF were created as two distinct and independent institutions with different tasks and methods of intervention, within the framework of the Bretton Woods agreement (1944). Up to the 1980s, the division of labor between the Fund and the Bank had been relatively straightforward. While the Fund's orientation was towards short-run macroeconomic stability, the Bank was oriented towards long-run development programs. At the same time the existence of synergies between the two institutions had also been recognized.

complementarities- strategic communication represents the primary source of loss for the two institutions.

${ }^{4}$ Moreover, in Marchesi Sirtori (2011) we focused on the number of IMF and WB programs rather than on the amount disbursed. 
Such synergies, however, became more important during the 70's and the 80's when, on the one hand, the IMF started to complement demand management policies by supply side policies and, on the other, the World Bank changed its policy towards a more explicit recognition of the importance of macroeconomic policies besides the traditional project and sector lending. Moreover, during the 1980s, the Fund's lending became more concessional and related to structural matters and increasingly focused on lower income countries, those typically "served" by the Bank.

The first step towards a formal recognition of the importance of cooperation between the IMF and the World Bank was already made in 1966 with an agreement which explicitly laid out the primary responsibilities of each organization and the procedures for the two to work together (Boughton 2001). Then, in 1974, a joint ministerial committee of the Boards of Governors of the Bank and the Fund - the Development Committee (DC) - was established, in charge of assuring high-level coordination and facilitating intergovernmental consensus-building on development issues.

Lately, in 1989, a Concordat was signed by the IMF and the World Bank in which a vast area of overlapping responsibilities was explicitly identified. In this common area, cooperation should have been pursued and strengthened: to this scope the Concordat did define guidelines and terms of the World Bank-Fund interaction, and the mechanisms for resolving potential conflicts between the sister organizations. Both institutions committed themselves to systematically exchange information concerning low and middle-income countries. Moreover, the Concordat encouraged them to exchange this information not only within their decision bodies, but also at the level of the operative staff.

In particular, the Concordat was motivated by the public nature of the disagreement between the Fund and the Bank about Argentina, in 1988. At that time, the rules on collaboration broke down when the World Bank announced a new loan to the country, before the IMF mission had completed its negotiations with the Argentinian authorities. This circumstance forced the two organizations to come up with a new agreement to guide collaboration (Woods, 2006). Later on, in 1998, during the Asian Crisis, a new episode of disagreement promoted the issuing of a joint statement by the Bank president and the Fund managing director on Bank-Fund collaboration (Mallaby 2004). In light of the greater overlap in operations, the leaders of the two organizations reaffirmed that a better collaboration was needed.

Despite all these official documents aimed at strengthening Bank-Fund cooperation, operations in middle-income countries are not yet guided by any formal collaborative tool. As a result, the Bank and the Fund cooperation hinges critically on discretional communication at the staff level. The case is different for low income countries. With the creation of 
the Structural Adjustment Facility (SAF) and the Enhanced Structural Adjustment Facility (ESAF), later renamed as the Poverty Reduction and Growth Facility (PRGF), structural adjustment has served to create an important area of overlap between the Bank and the Fund. ${ }^{5}$ To access this program the country has to elaborate a policy framework paper, that is the Poverty Reduction Strategy Paper (PRSPs), jointly with the staff of the Fund and the Bank. The process of drafting the PRSPs was designed to ensure the consistency of the Bank's and the Fund's stances, by encouraging them to develop a common view on the appropriate policy advice for the country.

In the same year, the Heavily Indebted Poor Countries (HIPC) initiative was enhanced as a direct outcome of a comprehensive review carried out by the International Development Association (IDA) and the IMF. The initiative entails a coordinated commitment to reduce and forgive large volumes of debt to the poorest and most indebted countries. Despite good intentions PRSPs revealed some weaknesses such as the asymmetry in the documents' operational importance in each organization, the lack of specificity in outlining policy targets, and the failure to effectively engage the borrowing government in the process. ${ }^{6}$

More recently, in 2007 the World Bank and the Fund signed a Joint Management Action Plan, which sets concrete steps to improve the culture of cooperation between the two institutions, emphasizing, on the one hand, that duplicate functions represent a waste of resources for both institutions and, on the other, that uncoordinated policy prescriptions can make it harder for recipients dealing with adjustment programs. The Plan calls for an improvement of coordination and communication and it also recommends to translate identified goodpractices concerning interaction into standard practices.

The issue of Fund Bank coordination is still debated nowadays and far form being settled. For example, the forthcoming IMF review on conditionality is expected to contain a fair amount of discussion about coordination with the World Bank. This is going to be crucial especially for middle income countries whose operations are not guided by any formal process, like the PRSP or the related facilities in the two organizations.

\footnotetext{
${ }^{5}$ In January 2010, three types of loans were created under the new Poverty Reduction and Growth Trust (PRGT) as part of a broader reform: the Extended Credit Facility (ECF), the Rapid Credit Facility (RCF) and the Standby Credit Facility (SCF). In particular, the ECF succeeds the PRGF as the Fund's main tool for providing medium-term support.

${ }^{6}$ In particular, country ownership has become a crucial component of successful poverty reduction and development (see also the discussion above).
} 


\section{Data}

As in Marchesi and Sirtori (2001) I consider only the cases in which the IMF and the WB are lending simultaneously to a recipient country. I am well aware that being involved simultaneously with the same country does not necessarily mean that these two organizations are actually working together. The Bank and Fund could lend simultaneously to the same country without any exchange of information as well as exchanging information also at a distance. However, ceteris paribus, it is plausible to believe that these institutions will be more likely to interact when simultaneously "involved" with the same country as compared to the case in which they are acting on their own.

Appendix D lists the 114 countries of the sample. These countries receive assistance predominately by the World Bank or by the World Bank and the IMF together. All countries have actually been implementing a World Bank program, at least for one year, thus, there is no country that has been with no assistance at all throughout the sample. Furthermore, there is no country that has exclusively received IMF assistance during the years of the sample and only eleven countries that never received a simultaneous IMF-WB loan. Thus, in most cases, more than one loan was active in the same year and in the same country.

The picture is different looking at the amount which was actually disbursed as there is a sizable difference in the loan size among the two institutions. As Figure 1 shows while the average value of a loan granted by the IMF reaches 3.5 percent of a country's GDP, the average size of a WB loan is at most one percent.

Finally, Figure 2 describes the evolution of IMF and WB loans. As we can see there is also a difference in the pattern of WB and IMF loans: while the former have been globally stable throughout the period, Fund disbursements have been overall increasing reaching their peak in at the beginning of the 2000 s and decreasing afterwords. ${ }^{7}$

\section{FIGURE 1 and FIGURE 2 HERE}

\subsection{Control Variables}

My choice of control variables follows the specification of Marchesi and Sirtori (2011), which, in turn, was based on a common specification in the literature analyzing the effects of both IMF and WB programs (and foreign aid). ${ }^{8}$ My selection then includes economic, institutional, and social variables. More specifically, I control for the log of GDP per capita at the start of each period, measures for human resources (life expectancy and fertility rate),

\footnotetext{
${ }^{7}$ The end of my sample is just before the beginning of the global financial crisis of 2007-08.

${ }^{8}$ Among others, see Barro and Lee (2005), Dreher (2006a) and Rajan and Subramanian (2008).
} 
investment as a percentage of GDP, a measure of openness (exports and imports over GDP), an index of democracy as defined in the Polity IV dataset (ranging from -10 to 10) and the CPIA index of the World Bank which measures the quality of policies and institutions (reflecting the Bank's internal evaluation of country performance and institutions). ${ }^{9}$

\subsection{Variables of interest}

My variables of interest should include the factors that may affect the quality of communication between the two organizations. This set of variables is made of three main types of indicators. First of all, I include variables which are meant to capture the salience of asymmetric information (i.e., the relevance of specialized "local information" relative to the general expertise of a multilateral organizations). Then, following Fabricius (2007), I consider the level of competition between the two institutions (or "domain dissent") in explaining Bank-Fund cooperation. ${ }^{10}$ Finally, I control for the possible role of political factors in inducing more or less cooperation between the two institutions.

Importance of the local knowledge. The quality and the extent of communication is jeopardized by the relative weight given to adaptation to local conditions as revealed by each institution specialized information. However, whenever local knowledge is easily accessible and no specialized expertise is needed to acquire it, distorted communication does not represent a problem anymore. To this respect, I use the quality of information transmission as a proxy of a country's transparency and thus of the salience of the private information between the two organizations. With a higher transparency it is easier to verify information and, therefore, to assess its relevance and importance for decisions and outcomes. As a consequence, as information asymmetry decreases, the cooperation between the Bank and the Fund should improve. I use the number of telephone lines per 100 inhabitants (World Telecommunications/ ICT Indicators Database 2011) as a proxy for the quality of information transmission. ${ }^{11}$ Higher values indicate higher quality, and thus less importance of differences in knowledge endowment.

As an additional proxy of a country's transparency I have also used the indicator of Informational Transparency and Accountability (Williams 2014), which is a measure for the

\footnotetext{
${ }^{9} \mathrm{I}$ also tried to include some measures for "education" and some of the ICRG indicators but missing data reduced the sample substantially, so I do not report the results below. I have also included the KOF Index of Globalization and its subcomponent on economic restrictions (Dreher 2006b) and the results are unchanged. Different specifications are available upon request.

${ }^{10}$ Fabricious (2007), drawing on field research, shows that whenever the Bank and the Fund agree on the boundaries of each other's operations (the so called domain consensus), they tend to speak with one voice.

${ }^{11}$ For more recent years, the availability of internet access might be a better proxy, but the use of this variable would substantially restrict our sample. The number of telephone lines correlates highly with this and other potential measures for the intensity of communication.
} 
general data transparency in a country. ${ }^{12}$ If transparency is generally higher, the degree of asymmetric information between the IMF and the WB decreases, which should in turn increase their cooperation. Moreover, in additional specifications (available on request), I also included press freedom, corruption, an index of "Social Globalization" (which considers personal contact, information flows and cultural proximity), the share of missing data (World Bank). ${ }^{13}$

Competition or domain dissent. I measure the potential for domain dissent considering the "scope" of IMF conditionality, namely the number of areas covered by an IMF program. Greater scope means greater room for overlap (i.e., the IMF is more likely to interfere with the WB's actions) which in principle would imply greater potential disagreement as to "who gets what for what purpose." Such disagreement might trigger two different responses: either expressing disagreement (voice) or withholding information (exit) (Hirshman, 1970). If "channels of negotiation" remain open, disagreement does not necessarily lead to distorted communication and lack of cooperation. Therefore, ex ante, it is not easy to define the expected outcome of an increase in the "scope" of IMF conditionality. ${ }^{14}$ As a consequence, contrary to intuition, it could happen that increasing the scope of IMF conditionality, at least to some extent, could actually improves the probability of letting channels of communication open between the two institutions, as there is more room for identifying different area of specialized competence.

To capture the scope of IMF conditionality I follow Marchesi et al. (2011) and build 20 categories, allocating all conditions to one of them, with the 20th category containing the residual. These categories refer to: Arrears, Balance of Payments/Reserves, the Capital Account, Central Bank Reform, Credit to Government, Debt, Exchange system, Financial sector, Governance, Government Budget, Monetary Ceiling, Pricing, Private Sector Reforms, Privatization, Public Sector, Social, Systemic, Trade and Wages \& Pensions. Clearly, these categories are to some extent arbitrary and some of them represent sub-categories of others. ${ }^{15}$

Political factors. The role of political factors in explaining the preferential treatment to allies

\footnotetext{
${ }^{12}$ The index is available for 190 countries, and is a composite indicator based on 29 sources. We use the combined index of political and information transparency.

13 "Missing data" shows the share of series for which there are no data available in a given country and year (out of the 250 series classified as "economics" in the World Bank's World Development Indicators, 2008).

${ }^{14}$ For example, according to Fabricious (2007), disagreements are more likely to be observed in macroeconomic policy, fiscal policy, and financial sector reform, while other policy areas (i.e., privatization, agricultural policy, trade policy, and aid coordination) would show a substantial domain consensus.

${ }^{15}$ I focus on the scope of IMF conditionality, while ignoring the WB conditions. In the sample, however, WB programs are much more common than IMF programs. Thus, what makes the difference in most cases is the (additional) intervention of the IMF. I find similar results controlling for the number of conditions in IMF programs.
} 
of major shareholders of International Financial Institutions (IFI) is well known. ${ }^{16}$ In this analysis I am interested to test how political aspects may affect Bank-Fund cooperation. On the one hand, if political interferences are "symmetric," it is reasonable to expect that they make the two institutions more willing to find an agreement. On the other hand, asymmetric political pressure could jeopardize the cooperation between the IMF and the WB. Following Dreher et al (2014), I control for whether a country has been a temporary member of the United Nations Security Council (UNSC) at time $t-2$ since this circumstance is likely to affect loan (and aid) disbursements, on average, in the following period (that is at time $t-1$ in this specification). To evaluate the overall effect on growth I then interact UNSC temporary membership (at time $t-2$ ) with a loan granted simultaneously by the IMF and the WB at time $t-1 .^{17}$

Appendix B contains details of the definitions and sources of the variables included in the regressions while the descriptive statistics are provided in Appendix C.

\section{Empirical Model}

I use data only restricted to countries which have received either a loan simultaneously by the IMF and the WB or none, that is a maximum of 114 developing countries over the period 1982-2008, over eight time periods in total. I am aware that this choice could in principle be affected by a selection problem as countries that request a joint IMF-WB joint loan may, in principle, have some special characteristics that make them different from countries that apply to only one of the two institutions. However, to test for the robustness of our results, I also estimate an alternative specification using the full sample of countries (see Table 2).

Since the effects of a loan can be evaluated only after a few years from the disbursement, all variables are averaged over three years. ${ }^{18}$ I consider the link between (a three year averaged) growth and the lagged values of a joint IMF-WB loan. Thus, I assume that the main effects of loans on growth occur, on average, three years after their disbursements.I estimate (using

\footnotetext{
${ }^{16}$ There is substantial empirical evidence linking a country's geopolitical proximity to the Fund's major shareholders with a variety of types of preferential treatment (Thacker 1999; Barro and Lee 2005; Dreher and Jensen 2007; Dreher et al. 2009a; Dreher et al. 2009b, Stone 2008; Moser and Sturm 2011). There is also some evidence documenting the influence of political aspects on the World Bank credit allocation (Dreher et al. 2009b; Sturm and Vreeland 2009; Kaja and Werker 2010; Kilby 2009).

${ }^{17}$ Dreher et al. (2009a) and (2009b) find both evidence of a preferential treatment by the IMF and the WB (respectively) for countries serving on the UNSC. More recently, Dreher et al. (2014) show that the effect of aid on economic growth is reduced by the share of years a country has served on the UNSC in the period the aid has been committed.

${ }^{18}$ In a similar setup Burnside and Dollar (2000) and Collier and Dollar (2001) use averages over four years, while Barro and Lee (2005) or Dreher (2006a) use five-year averages.
} 
OLS with standard errors clustered at the country level)

$$
G_{i t}=\alpha+\beta L_{i t-1}+\gamma X_{i t-1}+\delta L_{i t-1} * X_{i t-1}+\zeta Z_{i t}+\eta_{i}+\tau_{t}+u_{i t}
$$

where $G_{i t}$ represents per capita growth in country $i$ at period $t, L_{i t-1}$ denotes the (one-period) lagged values of the sum of IMF and WB loans received by country $i$ at period $t, X_{i t-1}$ is a vector containing my (one-period) lagged variables of interest, $L * X$ denote the effect that the variables of interest have on the simultaneous participation to an IMF-WB loan and $Z$ is a vector containing a set of control variables, used by the previous studies which I include contemporaneously. Finally, $\eta_{i}$ and $\tau_{t}$ denote country and time dummies, respectively, which allow us to control for both countries unobservables and common macroeconomic factors.

I use a OLS fixed-effect estimator with robust standard errors in order to correct for heteroskedasticity across countries. When estimating the growth regression by OLS there may be the problem with the endogeneity of both the IMF and the WB variables as adjustment programs are usually concluded in periods of economic crisis and obviously selection problems may also be related to the interaction term between IMF and World Bank programs. Nevertheless I decided to use OLS to estimate equation (1). The first reason is that I believe (as for example do Clemens et al. 2012 and Dreher et al. 2014) that OLS regressions are superior to 2SLS with questionable instruments. ${ }^{19}$ As Bazzi and Clemens (2013) show in more detail, previous papers in the aid effectiveness literature rely on weak instruments - especially, but not exclusively, those relying on internal instruments using "black box" GMM estimations. In particular, Dreher et al. (2013) and (2014) and Kilby (2012) have all recently shown how that politically driven aid (and WB projects) have negative outcomes. For this reason political variables cannot be (anymore) valid instruments in aid (and loans) effectiveness regressions.

The second reason is that my estimate of whether IMF-WB loans affects growth is likely to be the lower bound of the true effect. Most importantly, I avoid interpreting it in a causal way.

\section{Empirical results}

The results are presented in Table 1. Column 1 focus on IMF-WB simultaneous disbursements and on the main variables that are most commonly used in the literature analyzing the effects of both IMF and WB programs. Column 2 includes the variables of interest as

\footnotetext{
${ }^{19}$ Clemens et al. (2012) and Dreher et al (2014) address the potential endogeneity of aid by differencing the regression equation, using aid that is more likely to affect growth in the short-run, and lagging aid, so that it can reasonably be expected to cause growth rather than being its effect.
} 
well as the control variables, while column 3 contains only the variables of interest and their interactions with the (lagged) values of a joint IMF-WB loan. Finally column 4 includes all variables. While all these results are reported for comparison, I will largely base the discussion on the fully specified model of column 4

In column 1, I detect a positive and significant -at the one-percent level- correlation between a joint Bank-Fund loan and growth: an increase by one standard deviation of an IMF-WB loan increases per capita growth by almost 1.4 percent. Column 2 turns to all the interest variables. As can be seen, none of them is significant in this specification, while the other explanatory variables maintain similar signs and significance levels as in column 1 Column 3 includes only the variables of interest and their interactions with the lagged value of a joint IMF-WB loan, where none of them is significant as before.

Turning to the link between growth and a joint Bank-Fund loan, in column 4, as before the coefficient of a simultaneous IMF-WB loan is significant at the one percent level and substantively important: its increase by one standard deviation increases per capita growth by 0.7 percent. The finding of a positive coefficient is reassuring with respect to the (plausible) consequences of the endogeneity of an IMF and WB program adoption as in this case a downward bias in the estimate of such coefficient is expected.

Most explanatory variables have the expected impact on growth: growth rates increases with lower initial GDP, higher investments, and higher scores of the CPIA index, as expected. The coefficients of life fertility, life expectancy, openness and democracy are not significant at conventional levels.

As far as my variables of interest are concerned, I observe that the coefficient of the interaction between a joint IMF and WB loan with the variable information transmission is positive and significant at the one-percent level. However, in order to look at the specific effect of the IMF-WB loan at different levels of information transmission, I calculated the marginal effects of the interaction (as displayed in Figure 3). The results show that the link between a joint loan and economic growth is always significant, positive and increasing with information transmission. This evidence then suggests that the more easily the two institutions can gather country-specific information, the more beneficial their joint intervention in a country can become, which is consistent with my expectations. ${ }^{20}$

The coefficient of the interaction with scope is negative and insignificant. When I graph the marginal effect of Bank-Fund loans for different levels of scope (as displayed in Figure 4), the results show that the link between a joint loan and growth is positive and significant only for

\footnotetext{
${ }^{20}$ Similar results are obtained by including the indicator of Informational Transparency and Accountability instead of the Information Transmission (see Appendix A).
} 
a limited range of values of the number of areas covered by an IMF program (which is around the sample average). However, this relationship becomes insignificant with greater scope. This result suggests that, in line with my previous discussion, communication between the two institutions is easier when there are more intervention areas (i.e., greater scope), however, if they become too high, the two institutions become also more likely to find potential areas of dissent.

The interaction with the dummy for temporary UNSC membership is positive but insignificant at conventional levels (p-value 0.15). When I graph the marginal effect of Bank-Fund loans for different levels of (averaged) lagged UNSC membership (as displayed in Figure 5), the results show that the link with growth is positive and significant only for countries which has been, at most, temporary members for only one year out of the two-period membership. ${ }^{21}$ The results then suggest that the correlation between Bank-Fund loans and growth is positive and significant when such loans have been disbursed for political reasons. This result seem at odd with previous results of the literature showing the negative effects of politically motivated aid (Dreher et al. 2013 and 2014) and it is consistent with the hypothesis that political interferences make the two institutions willing to interact more effectively. ${ }^{22}$

TABLE 1 HERE

FIGURE 3, FIGURE 4 and FIGURE 5 HERE

\subsection{Robustness test}

As we mentioned in the previous section, in order to test for the robustness of my results, I also estimate an alternative specification using the full sample of countries, that is a maximum of 128 developing countries over the 1982-2008 period. The main advantage of this specification is that it allows us to distinguish between the effect of the money disbursed and that of simple participation. More specifically, I test the following equation

$$
\begin{aligned}
G_{i t}= & \alpha_{1}+\beta_{1} L_{i t-1}+\gamma_{1} X_{i t-1}+\delta_{1} L_{i t-1} * X_{i t-1}+\lambda d I W_{i t-1}+\mu L_{i t-1} * d I W_{i t-1}+ \\
& \nu d I W_{i t-1} * X_{i t-1}+\rho d I W_{i t-1} * L_{i t-1} * X_{i t-1}+\zeta_{1} Z_{i t}+\eta_{i}+\tau_{t}+\varepsilon_{i t}
\end{aligned}
$$

where $L$ denotes the sum of IMF and WB loans, $X$ is a vector containing the variables of interest, $d I W$ is a dummy variable which is equal to one when a country receive a loan

\footnotetext{
${ }^{21}$ The UNSC is made of five permanent members (China, France, Russian Federation, United Kingdom and United States) with veto power and of ten elected members nominated by regional caucus (in turn elected by the UN General Assembly) with a two-year term limits.

${ }^{22}$ Similar results are obtained controlling for whether a country votes (more or less) in line with the United States in the United Nations General Assembly (UNGA).
} 
simultaneously by the IMF and the WB, $d I W * L$ denotes the effect of a simultaneous IMFWB loan and $d I W * L * X$ denotes the effect of the variables of interest interacted with a simultaneous IMF-WB loan. ${ }^{23}$ As above, $Z$ is a vector containing a set of control variables and $\eta_{i}$ and $\tau_{t}$ denote country and time dummies, respectively.

Table 2 presents the results of the "full" specification in equation (2). Looking at column 1 , first of all, we observe a difference between the effect of the money disbursed in a joint IMF-WB loan and that of simple participation. Lagged participation is associated with a significant, at the five percent level, increase in per capita growth by one percent, while the lagged coefficient of the variable denoting their simultaneous loans is negative and significant at the five-percent level.

Moreover, we can observe that while the lagged value of the sum of IMF or WB disbursements correlates positively with growth at the one-percent level of significance, the coefficient of the variable denoting their (lagged) simultaneous presence is negative but smaller than the first one. Since the coefficient of the sum of Bank-Fund disbursements is larger than the coefficient of a joint disbursement, the overall effect remains a positive one. As above, most explanatory variables have the expected impact on growth.

As above I focus on the results of the most complete specification presented in column 4 . Turning to the interaction terms, on the one hand, we can detect some differences between the interaction with the dummy for IMF-WB simultaneous participation and that with an IMF-WB simultaneous loan. On the other hand, focusing on the latter, as we can see the coefficient of the interaction between Fund-Bank joint loans and information transmission is, as before positive and significant at the one-percent level, the coefficient of the interaction with lagged scope is still negative but now significant at the five-percent level. Finally, the interaction between Fund-Bank joint loans and lagged UNSC membership is instead now negative, rather than positive. It then seems that, when separating the effect of the amount disbursed from that of simple participation, politically motivated loans are associated to lower growth, consistently with previous results in the (aid) literature (see, for example, Dreher et al. 2014). ${ }^{24}$

\section{TABLE 2 HERE}

\section{FIGURE 6, FIGURE 7 and FIGURE 8 HERE}

In summary, the empirical analysis confirms that Bank-Fund simultaneous intervention is associated to an increase in economic growth and that such effect is increasing with the avail-

\footnotetext{
${ }^{23}$ Since $X * L * d I W$ is a triple interaction I should control for each possible combination of these three variables.

${ }^{24}$ Marginal effects are available upon request.
} 
ability of the country's specific information (which decreases the asymmetry of information between the two institutions), and -at least to some extent- with the scope of IMF's conditionality (which makes communication easier for the two institutions by decreasing their competition). Political interferences are also shown to enhance Fund-Bank effectiveness. The next section provides policy implications and concludes.

\section{Conclusions}

In this paper I relate Bank-Fund performance to their willingness (or ability) to communicate. As a measure of their performance I take the relationship between a Bank-Fund simultaneous loan and recipient country's growth and I find that Bank-Fund simultaneous intervention is associated to an increase in economic growth (as in Marchesi and Sirtori, 2011) and that such effect is increasing with the availability of the country's specific information, to some extent, with the scope of IMF's conditionality and with geopolitical determinants of Fund-Bank loans.

This paper provides an empirical foundation to a large number of official reports encouraging more information sharing between the two institutions. More specifically, focusing on the importance of (strategic) communication, some policy indications could also be derived on how to ameliorate cooperation between IMF and WB. For example, the introduction of clear guidelines on information sharing between Bank and Fund staff would probably ameliorate the existing distortions, likewise, a stronger division of labor would also help to remove competition problems.

Furthermore, this analysis could be extended to consider the interaction of other types of international organizations (it would be, for instance, of particular interest to consider cooperation within the Troika during the recent European debt crisis) and even to donors' coordination. In particular, it is now widely recognized that foreign aid in the typical developing country is highly fragmented and the so-called "new rhetoric on aid" clearly identifies aid fragmentation, and the related coordination failure, as one of the main problems in aid allocation (e.g., see the Paris Declaration on Aid Effectiveness, OECD 2005).

The analysis is of course limited. I do not claim to draw causal inferences from the empirical analysis, given the nature of the data available. I do emphasize that the direction of causality in the relationship between Bank-Fund's loans and growth raises some questions and thus a robust association between IMF-WB intervention and growth can only be indicative of a correlation between the two variables. I hope, however, to have shown that the task is worthwhile and that the conclusions can be instructive. 


\section{References}

[1] Barro R.J. and J.W Lee (2005) "IMF Programs: who is chosen and what are the effects?" Journal of Monetary Economics, 52, 1245-1269.

[2] Boughton J. (2001) "Silent Revolution: The International Monetary Fund, 19791989." Washington: International Monetary Fund.

[3] Burnside C., and D. Dollar (2000) "Aid, Policies and Growth." American Economic Review 90, 847-868.

[4] Collier P. and D. Dollar (2002). "Aid allocation and poverty reduction." European Economic Review 46, 1475-1500.

[5] Clemens, C., Radelet S., Bhavnani R., and S. Bazzi (2012) "Counting chickens when they hatch: Timing and the Effects of Aid on Growth." Economic Journal 122, 561: 590-617.

[6] Crawford V., and J.Sobel. (1982) "Strategic Information Transmission." Econometrica, $50,1431-1451$.

[7] Dixit A. (2009) "Governance, Institutions and Economic Activity." American Economic Review 99, pp. 5-24.

[8] Dreher A. (2006a), "IMF and economic growth: the effects of programs, loans and compliance with conditionality." World Development, 34, 769-788.

[9] Dreher A. (2006b) "Does Globalization Affect Growth? Evidence from a new Index of Globalization." Applied Economics, 38, 1091-1110.

[10] Dreher A. and N.M. Jensen (2007) "Independent Actor or Agent? An Empirical Analysis of the Impact of U.S. Interests on IMF Condition." Journal of Law and Economics, $50,105-124$.

[11] Dreher A., Sturm J-E, and J.R Vreeland (2009a) "Global Horse Trading: IMF loans for votes in the United Nations Security Council." European Economic Review, 53, 742-757.

[12] Dreher A., Sturm J-E, and J.R Vreeland (2009b) "Development Aid and International Politics: Does membership on the UN Security Council influence World Bank decisions?" Journal of Development Economics, 88, 1-18. 
[13] Dreher A., Klasen S., Vreeland J.R. and E. Werker, (2013) The costs of favoritism: Is politically-driven aid less effective? Economic Development and Cultural Change, forthcoming.

[14] Dreher, A., V. Eichenauer, and K. Gehring (2014). Geopolitics, Aid and Growth. CEPR Discussion Paper 9904.

[15] Easterly W. (2006) “The White Man's Burden: Why the West's Efforts to Aid the Rest Have Done So Much Ill and So Little Good." London: The Penguin Press.

[16] Easterly W. (2008) "Institutions: Top Down or Bottom Up?", American Economic Review, Papers and Proceedings, 98, 95-99.

[17] Easterly W. (2013) "The Tyranny of Experts" New York: Basic Books.

[18] Fabricius M. (2007) "Merry Sisterhood or Guarded Watchfulness? Cooperation Between the International Monetary Fund and the World Bank." WP $07-9$ Peterson Institute for International Economics.

[19] Hirschman A. O. (1970) "Exit, Voice, and Loyalty: Responses to Decline in Firms, Organizations, and States." Harvard University Press.

[20] IMF (1998). External Evaluation of Enhanced Structural Adjustment Facility (ESAF): Report by a Group of Independent Experts.

[21] Kaja A. and E. Werker (2010) "Corporate Misgovernance at the World Bank and the Dilemma of Global Governance.” World Bank Economic Review, 24, 171-198.

[22] Kilby C. (2009) "The political economy of conditionality: An empirical analysis of World Bank loan disbursements." Journal of Development Economics, 89, 1, 51-61.

[23] Kilby, C. (2013) "The political economy of project preparation: An empirical analysis of World Bank projects." Journal of Development Economics, 105: 211-225

[24] Krueger A. (1997) "Wither the World Bank and the IMF?" NBER Working Paper 6327.

[25] IMF (2007) Malan Report .Report Of The External Review Committee On Bank-Fund Collaboration. Available online: www.imf.org/external/np/pp/eng/2007/2022307.pdf

[26] IMF (2010) Implementation of the Joint Management Action Plan on Bank-Fund Collaboration. Available on line: www.imf.org/external/np/pp/eng/2010/030310.pdf 
[27] IMF and World Bank (2001) Strengthening IMF-World Bank Collaboration on Country Programs and Conditionality (August).

[28] IMF and World Bank (2007) Final Report of the external review committee on BankFund collaboration (February).

[29] Mallaby S. (2004) "The World's Banker: A Story of Failed States, Financial Crises, and the Wealth and Poverty of Nations." Council on Foreign Relations Books, Penguin Press.

[30] Marchesi S., Sabani L. and A. Dreher (2011), "Read my lips: the role of information transmission in multilateral reform design." Journal of International Economics, 2011, 84, pp. 86-98.

[31] Marchesi S, and E. Sirtori (2011) "Is two better than one? Effects on growth of BankFund interaction." Review of International Organization, 2011, 6, pp 287-306.

[32] Marshall M.G. and K. Jaggers (2009) "Polity IV Project: Political Regime Characteristics and Transitions, 1800-2007." University of Maryland.

[33] Moser, C. and J.-E. Sturm (2011): "Explaining IMF Lending Decisions after the Cold War." The Review of International Organizations, 6(3), 307-340.

[34] OECD (2005) The Paris Declaration on Aid Effectiveness and the Accra Agenda for Action. Available from: www.oecd.org/dataoecd/11/41/34428351.pdf.

[35] PRS Group (1998) "International Country Risk Guide (ICRG)" 19, 4. Syracuse, NY: IBC. http://www.prsgroup.com

[36] Rajan R. (2008) "The future of the IMF and the World Bank." American Economic Review, Papers and Proceedings, 98, 110-115.

[37] Rajan R., and A. Subramanian (2008) "Aid and growth: what does the evidence really show." The Review of Economics and Statistics, 90(4): 643-665.

[38] Stone R. (2008) "The Scope of IMF Conditionality: How Autonomous is the Fund?" International Organization, 62, 589-620.

[39] Thacker S. (1999) "The High Politics of IMF Lending." World Politics, 52, 38-75.

[40] The Economist "The UN and the World Bank: Rare co-operation." Jun 1st 2013. 
[41] Voeten E. (2004) "Documenting Votes in the UN General Assembly." http://home.gwu.edu/ voeten/UNVoting.htm

[42] Williams, A., 2014, A global index of information transparency and accountability, Journal of Comparative Economics, Forthcoming.

[43] Woods N. (2006) "The Globalizers. The IMF, the World Bank, and their Borrowers." Cornell University Press.

[44] World Bank (2008), World Development Indicators, CD-Rom. Washington, D.C. 


\section{(1)}

IMF \& WB loans (t-1)
Information transmission $(\mathrm{t}-1)$

Scope $(\mathrm{t}-1)$

UNSC (t-2)

Initial per cap. GDP (log)

Investment

Openness

\section{CPIA}

Life fertility (log)

Life expectancy $(\log )$

Democracy

IMF \& WB loans $x$ Info transmission ( $t-1)$

IMF \& WB loans x Scope ( $\mathrm{t}-1)$

IMF \& WB loans (t-1) x UNSC (t-2)

Constant

Observations

Country FE

Time FE

R-squared

Number of id

\begin{tabular}{|c|c|c|c|}
\hline \multirow{8}{*}{$\begin{array}{c}0.235^{* * *} \\
(4.388)\end{array}$} & $0.164^{* * *}$ & $0.159^{* *}$ & $0.116^{* *}$ \\
\hline & $(4.252)$ & (2.398) & $(2.422)$ \\
\hline & -0.004 & -0.109 & $-0.105^{*}$ \\
\hline & $(-0.080)$ & $(-1.485)$ & $(-1.714)$ \\
\hline & -0.039 & 0.077 & -0.005 \\
\hline & $(-0.516)$ & $(0.630)$ & $(-0.047)$ \\
\hline & -0.532 & -1.109 & -0.651 \\
\hline & $(-0.795)$ & $(-1.287)$ & $(-1.005)$ \\
\hline-3.077 & $-3.930^{*}$ & & $-3.733^{*}$ \\
\hline$(-1.519)$ & $(-1.880)$ & & $(-1.682)$ \\
\hline $0.088^{* *}$ & $0.096^{* * *}$ & & $0.104^{* * *}$ \\
\hline$(2.262)$ & $(2.924)$ & & (3.138) \\
\hline 0.010 & 0.012 & & 0.010 \\
\hline$(0.767)$ & $(0.856)$ & & $(0.717)$ \\
\hline $2.321^{* * *}$ & $2.766^{* * *}$ & & $2.750^{* * *}$ \\
\hline$(6.207)$ & $(6.292)$ & & $(6.331)$ \\
\hline-3.115 & 0.521 & & 1.455 \\
\hline$(-1.534)$ & $(0.210)$ & & $(0.580)$ \\
\hline-0.904 & 0.330 & & 0.275 \\
\hline$(-0.187)$ & $(0.072)$ & & $(0.062)$ \\
\hline-0.044 & -0.032 & & -0.038 \\
\hline \multirow[t]{7}{*}{$(-0.977)$} & $(-0.836)$ & & $(-0.956)$ \\
\hline & & 0.010 & $0.017^{* * *}$ \\
\hline & & (1.338) & $(3.217)$ \\
\hline & & -0.008 & -0.008 \\
\hline & & $(-0.555)$ & $(-0.647)$ \\
\hline & & 0.611 & 0.822 \\
\hline & & $(0.826)$ & (1.436) \\
\hline 20.168 & 14.561 & $3.883^{* * *}$ & 12.838 \\
\hline$(0.885)$ & $(0.618)$ & $(4.991)$ & $(0.541)$ \\
\hline 542 & 466 & 535 & 466 \\
\hline YES & YES & YES & YES \\
\hline YES & YES & YES & YES \\
\hline 0.279 & 0.324 & 0.179 & 0.337 \\
\hline 96 & 94 & 112 & 94 \\
\hline
\end{tabular}

Notes: The dependent variable is the average of the per capita GDP growth rate over the 3-year periods: 1982-1984, 1985-1987, . . . 2006-2008. t-statistics in parentheses. Standard errors are clustered at the country level, ${ }^{*} \mathrm{p}<0.10,{ }^{* *} \mathrm{p}<0.05,{ }^{* * *} \mathrm{p}<0.01$. $^{* * *}$ 


\begin{tabular}{|c|c|c|c|c|}
\hline & $\overline{(1)}$ & $\overline{(2)}$ & 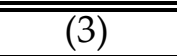 & $(\overline{(4)}$ \\
\hline IMF + WB loans (-1) & $\begin{array}{c}0.231^{* * *} \\
(3.955)\end{array}$ & $\begin{array}{c}0.280^{* * *} \\
(4.297)\end{array}$ & $\begin{array}{l}0.265^{* * *} \\
(20.452)\end{array}$ & $\begin{array}{c}0.852^{* * *} \\
(4.757)\end{array}$ \\
\hline IMF \& WB loans (t-1) & $\begin{array}{l}-0.132^{* *} \\
(-2.212)\end{array}$ & $\begin{array}{l}-0.151^{* *} \\
(-2.363)\end{array}$ & $\begin{array}{c}-0.182^{* * *} \\
(-3.961)\end{array}$ & $\begin{array}{c}-0.753^{* * *} \\
(-4.206)\end{array}$ \\
\hline dIMF\&WB (-1) & $\begin{array}{l}1.048^{* *} \\
(2.035)\end{array}$ & $\begin{array}{c}1.066^{*} \\
(1.907)\end{array}$ & $\begin{array}{c}-0.052 \\
(-0.075)\end{array}$ & $\begin{array}{c}0.695 \\
(1.166)\end{array}$ \\
\hline Information transmission $(\mathrm{t}-1)$ & & $\begin{array}{c}-0.035 \\
(-0.743)\end{array}$ & $\begin{array}{c}-0.192^{* * *} \\
(-3.133)\end{array}$ & $\begin{array}{c}-0.042 \\
(-0.569)\end{array}$ \\
\hline IMF \& WB $x$ Info transmission (t-1) & & & $\begin{array}{c}0.052 \\
(0.619)\end{array}$ & $\begin{array}{c}0.023 \\
(0.343)\end{array}$ \\
\hline $\mathrm{IMF}+$ WB loans $x$ Info transmission $(\mathrm{t}-1)$ & & & $\begin{array}{c}0.024 \\
(0.562)\end{array}$ & $\begin{array}{c}-0.285^{* * *} \\
(-4.047)\end{array}$ \\
\hline IMF \& WB loans $x$ Info transmission $(\mathrm{t}-1)$ & & & $\begin{array}{c}-0.014 \\
(-0.329)\end{array}$ & $\begin{array}{c}0.296^{* * *} \\
(4.254)\end{array}$ \\
\hline Scope $(t-1)$ & & $\begin{array}{c}-0.029 \\
(-0.412)\end{array}$ & $\begin{array}{c}-0.025 \\
(-0.082)\end{array}$ & $\begin{array}{c}0.285 \\
(1.249)\end{array}$ \\
\hline IMF \& WB x Scope $(\mathrm{t}-1)$ & & & $\begin{array}{c}0.056 \\
(0.186)\end{array}$ & $\begin{array}{c}-0.285 \\
(-1.174)\end{array}$ \\
\hline IMF + WB loans $x$ Scope $(t-1)$ & & & $\begin{array}{c}0.020 \\
(0.344)\end{array}$ & $\begin{array}{l}-0.109^{* *} \\
(-2.484)\end{array}$ \\
\hline IMF \& WB loans x Scope $(t-1)$ & & & $\begin{array}{c}-0.023 \\
(-0.385)\end{array}$ & $\begin{array}{l}0.104^{* *} \\
(2.226)\end{array}$ \\
\hline UNSC (t-2) & & $\begin{array}{c}-0.482 \\
(-0.865)\end{array}$ & $\begin{array}{c}-0.993 \\
(-0.698)\end{array}$ & $\begin{array}{c}-0.941 \\
(-1.033)\end{array}$ \\
\hline $\operatorname{IMF} \&$ WB $(\mathrm{t}-1) \times \operatorname{UNSC}(\mathrm{t}-2)$ & & & $\begin{array}{c}0.678 \\
(0.369)\end{array}$ & $\begin{array}{c}0.317 \\
(0.235)\end{array}$ \\
\hline $\mathrm{IMF}+$ WB loans $(\mathrm{t}-1) \times \mathrm{UNSC}(\mathrm{t}-2)$ & & & $\begin{array}{l}2.183^{*} \\
(1.808)\end{array}$ & $\begin{array}{c}4.106^{* * *} \\
(5.474)\end{array}$ \\
\hline IMF \& WB loans (t-1) x UNSC (t-2) & & & $\begin{array}{l}-2.277^{*} \\
(-1.860)\end{array}$ & $\begin{array}{l}-4.127^{* * *} \\
(-5.410)\end{array}$ \\
\hline Initial per cap. GDP (log) & $\begin{array}{l}-2.920^{* *} \\
(-2.350)\end{array}$ & $\begin{array}{l}-3.152^{*} \\
(-1.981)\end{array}$ & & $\begin{array}{l}-2.946^{* *} \\
(-2.097)\end{array}$ \\
\hline Investment & $\begin{array}{c}0.107^{* * *} \\
(3.842)\end{array}$ & $\begin{array}{c}0.104^{* * *} \\
(3.629)\end{array}$ & & $\begin{array}{c}0.116^{* * *} \\
(3.921)\end{array}$ \\
\hline Openness & $\begin{array}{c}0.012 \\
(1.230)\end{array}$ & $\begin{array}{c}0.008 \\
(0.752)\end{array}$ & & $\begin{array}{c}0.003 \\
(0.291)\end{array}$ \\
\hline CPIA & $\begin{array}{c}2.137^{* * *} \\
(8.062)\end{array}$ & $\begin{array}{c}2.650^{* * *} \\
(6.660)\end{array}$ & & $\begin{array}{c}2.453^{* * *} \\
(5.991)\end{array}$ \\
\hline Life fertility (log) & $\begin{array}{c}0.720 \\
(0.454)\end{array}$ & $\begin{array}{c}1.175 \\
(0.608)\end{array}$ & & $\begin{array}{c}1.001 \\
(0.602)\end{array}$ \\
\hline Life expectancy (log) & $\begin{array}{c}-0.640 \\
(-0.213)\end{array}$ & $\begin{array}{c}-0.757 \\
(-0.239)\end{array}$ & & $\begin{array}{c}-0.465 \\
(-0.153)\end{array}$ \\
\hline Democracy & $\begin{array}{c}-0.006 \\
(-0.184)\end{array}$ & $\begin{array}{c}-0.009 \\
(-0.234)\end{array}$ & & $\begin{array}{c}-0.001 \\
(-0.023)\end{array}$ \\
\hline Constant & $\begin{array}{l}13.422 \\
(0.900)\end{array}$ & $\begin{array}{l}13.707 \\
(0.830)\end{array}$ & $\begin{array}{c}4.854^{* * *} \\
(7.161)\end{array}$ & $\begin{array}{l}12.202 \\
(0.793)\end{array}$ \\
\hline
\end{tabular}


Observations

665

589

747

589

Country FE

YES

YES

YES

YES

Time FE

YES

YES

YES

YES

R-squared

0.298

0.330

0.398

0.365

Number of id

105

104

118

104

Notes: The dependent variable is the average of the per capita GDP growth rate over the 3-year periods: 1982-1984, 1985-1987, . . , 2006-2008. t-statistics in parentheses.

Standard errors are clustered at the country level, ${ }^{*} \mathrm{p}<0.10,{ }^{* *} \mathrm{p}<0.05,{ }^{* * *} \mathrm{p}<0.01 .{ }^{* * *}$ 
Figure 1

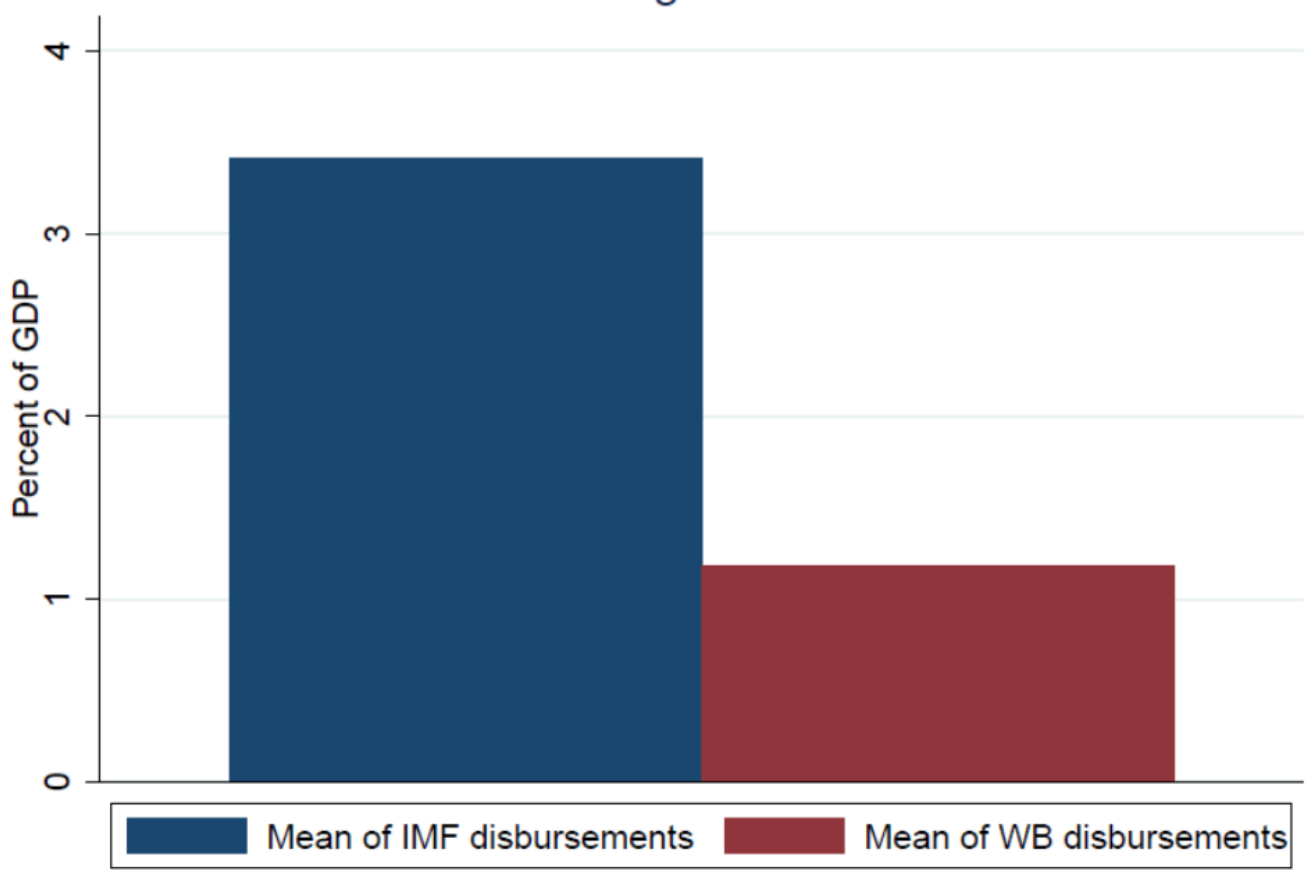

Figure 2

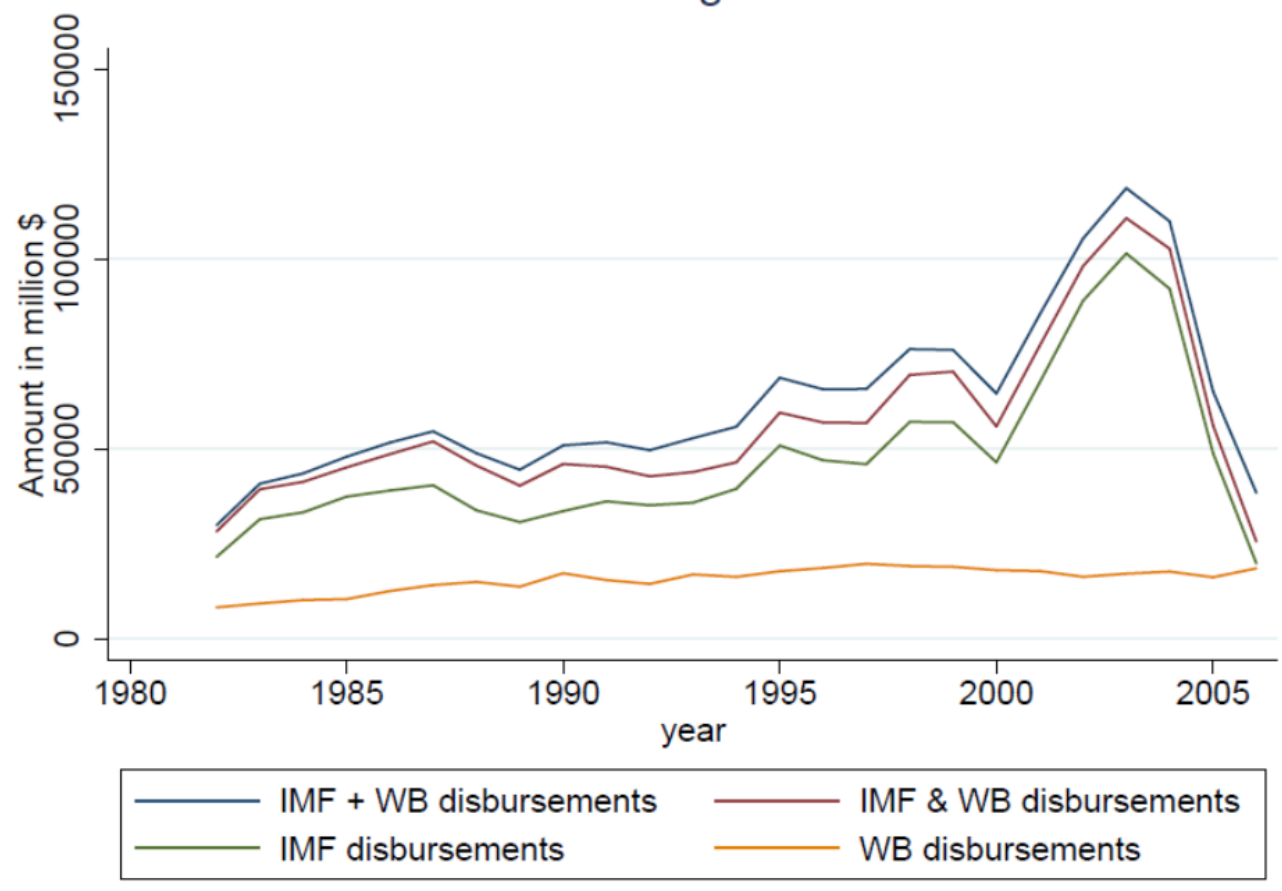




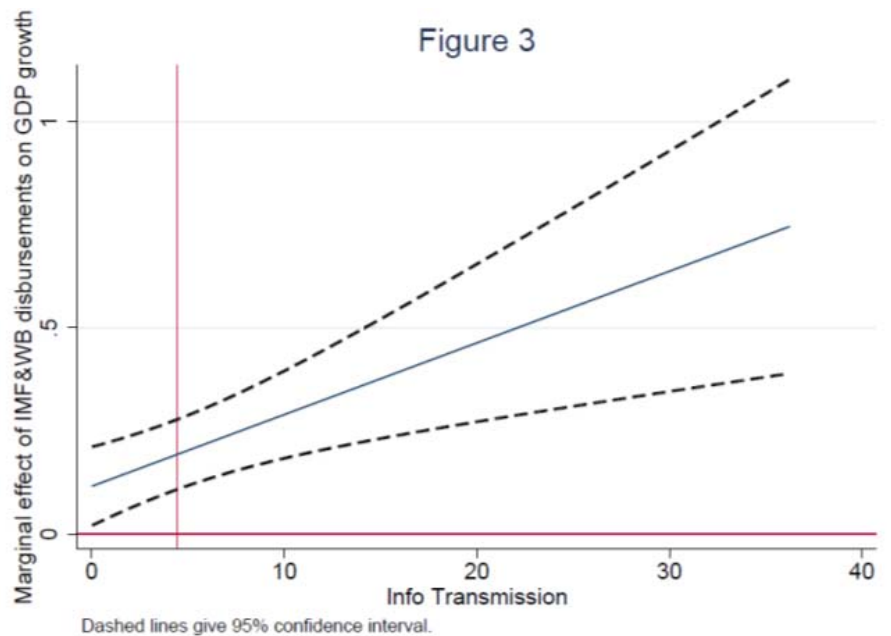

Figure 3: Marginal effect of lagged values of IMF and WB loans on growth for different levels of Information Transmission (Table 1). The dashed line shows the 95\%-confidence interval.

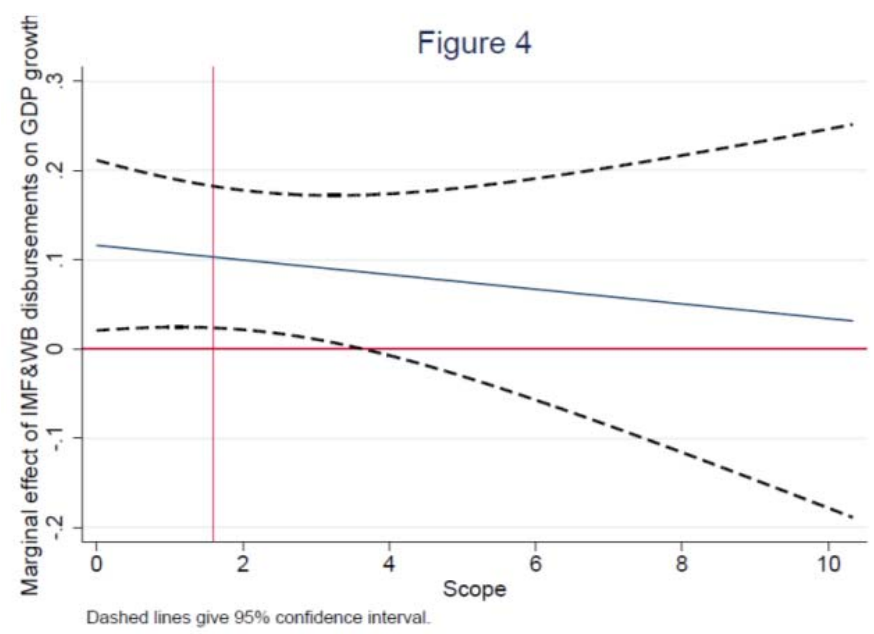

Figure 4: Marginal effect of lagged values of IMF and WB loans on growth for different levels of Scope (Table 1). The dashed line shows the $95 \%$-confidence interval.

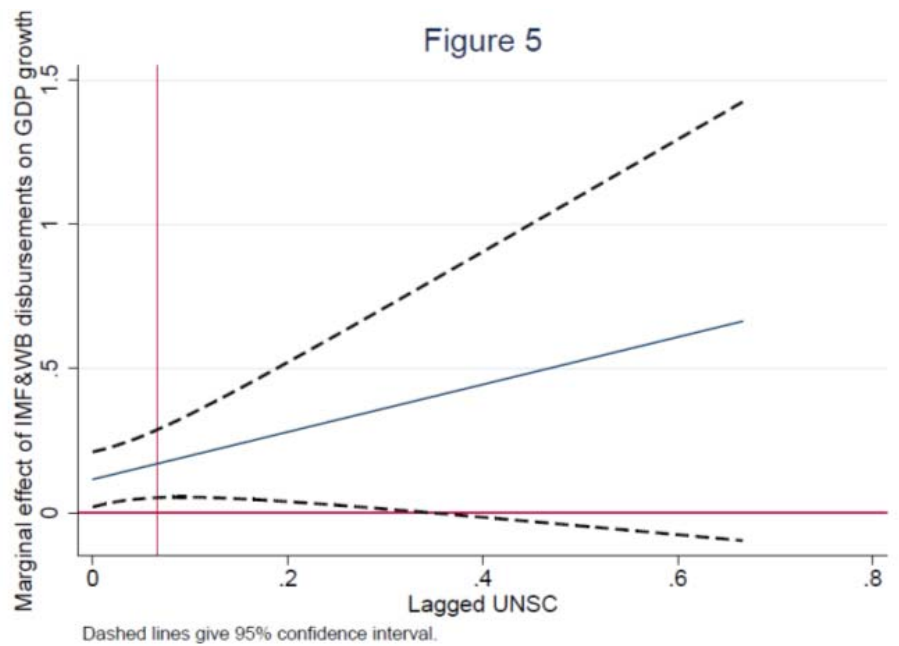

Figure 5: Marginal effect of lagged IMF and WB loans on growth for different levels of UNSC temporary membership at time $t-2$. The dashed line shows the $95 \%$-confidence interval. 


\begin{tabular}{|c|c|c|c|c|}
\hline & $(1)$ & $(2)$ & (3) & $(4)$ \\
\hline IMF \& WB loans (t-1) & $\begin{array}{c}0.235^{* * *} \\
(4.388)\end{array}$ & $\begin{array}{c}0.160^{* * *} \\
(4.099)\end{array}$ & $\begin{array}{c}0.101 \\
(0.593)\end{array}$ & $\begin{array}{c}-0.051 \\
(-0.414)\end{array}$ \\
\hline Transparency $(\mathrm{t}-1)$ & & $\begin{array}{c}0.036 \\
(1.088)\end{array}$ & $\begin{array}{c}-0.005 \\
(-0.087)\end{array}$ & $\begin{array}{c}0.003 \\
(0.085)\end{array}$ \\
\hline Scope $(t-1)$ & & $\begin{array}{c}-0.034 \\
(-0.453)\end{array}$ & $\begin{array}{c}0.078 \\
(0.634)\end{array}$ & $\begin{array}{c}-0.003 \\
(-0.023)\end{array}$ \\
\hline UNSC (t-2) & & $\begin{array}{c}-0.537 \\
(-0.810)\end{array}$ & $\begin{array}{c}-1.181 \\
(-1.390)\end{array}$ & $\begin{array}{c}-0.678 \\
(-1.061)\end{array}$ \\
\hline Initial per cap. GDP (log) & $\begin{array}{c}-3.077 \\
(-1.519)\end{array}$ & $\begin{array}{l}-4.244^{* *} \\
(-2.045)\end{array}$ & & $\begin{array}{l}-4.187^{*} \\
(-1.927)\end{array}$ \\
\hline Investment & $\begin{array}{l}0.088^{* *} \\
(2.262)\end{array}$ & $\begin{array}{c}0.103^{* * *} \\
(3.212)\end{array}$ & & $\begin{array}{c}0.105^{* * *} \\
(3.250)\end{array}$ \\
\hline Openness & $\begin{array}{c}0.010 \\
(0.767)\end{array}$ & $\begin{array}{c}0.011 \\
(0.790)\end{array}$ & & $\begin{array}{c}0.012 \\
(0.853)\end{array}$ \\
\hline CPIA & $\begin{array}{c}2.321^{* * *} \\
(6.207)\end{array}$ & $\begin{array}{c}2.694^{* * *} \\
(6.441)\end{array}$ & & $\begin{array}{r}2.769^{* * *} \\
(6.812)\end{array}$ \\
\hline Life fertility (log) & $\begin{array}{c}-3.115 \\
(-1.534)\end{array}$ & $\begin{array}{c}0.769 \\
(0.299)\end{array}$ & & $\begin{array}{c}0.564 \\
(0.222)\end{array}$ \\
\hline Life expectancy (log) & $\begin{array}{c}-0.904 \\
(-0.187)\end{array}$ & $\begin{array}{c}-0.012 \\
(-0.003)\end{array}$ & & $\begin{array}{c}-0.350 \\
(-0.084)\end{array}$ \\
\hline Democracy & $\begin{array}{c}-0.044 \\
(-0.977)\end{array}$ & $\begin{array}{c}-0.035 \\
(-0.924)\end{array}$ & & $\begin{array}{c}-0.039 \\
(-1.022)\end{array}$ \\
\hline IMF \& WB loans x Transparency (t-1) & & & $\begin{array}{c}0.002 \\
(0.638)\end{array}$ & $\begin{array}{l}0.005^{*} \\
(1.907)\end{array}$ \\
\hline IMF \& WB loans x Scope $(\mathrm{t}-1)$ & & & $\begin{array}{c}-0.006 \\
(-0.440)\end{array}$ & $\begin{array}{c}-0.006 \\
(-0.465)\end{array}$ \\
\hline IMF \& WB loans (t-1) x UNSC (t-2) & & & $\begin{array}{c}0.536 \\
(0.720)\end{array}$ & $\begin{array}{c}0.881 \\
(1.471)\end{array}$ \\
\hline Constant & $\begin{array}{l}20.168 \\
(0.885)\end{array}$ & $\begin{array}{l}15.784 \\
(0.710)\end{array}$ & $\begin{array}{c}3.271 \\
(1.084)\end{array}$ & $\begin{array}{l}18.251 \\
(0.801)\end{array}$ \\
\hline Observations & 542 & 466 & 535 & 466 \\
\hline Country FE & YES & YES & YES & YES \\
\hline Time FE & YES & YES & YES & YES \\
\hline R-squared & 0.279 & 0.327 & 0.174 & 0.333 \\
\hline Number of id & 96 & 94 & 112 & 94 \\
\hline
\end{tabular}

Notes: The dependent variable is the average of the per capita GDP growth rate over the 3-year periods: 1982-1984, 1985-1987, . . , 2006-2008. t-statistics in parentheses. Standard errors are clustered at the country level, ${ }^{*} \mathrm{p}<0.10,{ }^{* *} \mathrm{p}<0.05,{ }^{* *} \mathrm{p}<0.01$. $^{* *}$ 
Appendix B: Sources and definition of selected variables

\begin{tabular}{|c|c|c|}
\hline Variable & Definition & Source \\
\hline \multicolumn{3}{|l|}{ DEPENDENT VARIABLE } \\
\hline GDP growth & Per capita GDP (constant 2000 US\$) & WDI (2008) \\
\hline \multicolumn{3}{|l|}{ VARIABLES OF INTEREST } \\
\hline $\mathrm{IMF}+\mathrm{WB}$ loans & Sum of IMF and WB loans (ratio to GDP, percent) & WDI (2008) \\
\hline dIMF\&WB & dummy=1 in case of IMF-WB joint participation & Built by authors \\
\hline IMF \& WB loans & Sum of IMF and WB loans interacted with dIMF\&WB & Built by authors \\
\hline Info transmission & Fixed telephone lines per 100 inhabitants & World Telecommunication database \\
\hline Info transparency & Composite global index of information transparency & Williams (2014) \\
\hline Scope & Areas covered by Conditions & IMF's MONA database (2008) \\
\hline UNSC Membership & Share of years a country has served on the UNSC in a given period & Dreher et al. (2009a) \\
\hline IMF \& WB loans $x$ Info transmission & IMF \& WB loans interacted with Info transmission & Built by authors \\
\hline IMF \& WB loans x Transparency & IMF \& WB loans interacted with Transparency & Built by authors \\
\hline IMF \& WB loans x Scope & IMF \& WB loans interacted with Scope & Built by authors \\
\hline IMF \& WB loans $x$ UNSC & IMF \& WB loans interacted with UNSC & Built by authors \\
\hline \multicolumn{3}{|l|}{ CONTROL VARIABLES } \\
\hline Initial per cap. GDP (log) & Log of per capita GDP at the beginning of the period & WDI (2008) \\
\hline Investment & Gross fixed capital formation (ratio to GDP) & WDI (2008) \\
\hline Openness & Export + Import of goods and services & WDI (2008) \\
\hline CPIA & Country Policy and Institutional Assessment & World Bank \\
\hline Life fertility (log) & Fertility rate (birth per woman) & WDI (2008) \\
\hline Life exp. $(\log )$ & Log of life expectancy & WDI (2008) \\
\hline Democracy & Polity2 score taken from the Polity IV dataset & Marshall and Jaggers (2009) \\
\hline
\end{tabular}


Appendix C Descriptive statistics (Estimation sample of Table 1)

\begin{tabular}{lcccc}
\hline \hline Variable & Mean & SD & Min & Max \\
\hline & & & & \\
Per capita growth & 1.7 & 5.37 & -30.8 & 55.93 \\
IMF \& WB loans & 4.27 & 6.03 & 0 & 50.53 \\
Information transmission & 6.67 & 8.4 & 0.02 & 48.47 \\
Information transparency & 47.58 & 14.55 & 3 & 81.33 \\
Scope & 0.92 & 1.86 & 0 & 10.33 \\
UNSC & 0.06 & 0.17 & 0 & 1 \\
Initial per cap. GDP $(\log )$ & 6.83 & 1.11 & 4.11 & 9.11 \\
Investment & 22.65 & 8.81 & 2.56 & 88 \\
Openness & 77.59 & 39.37 & 9.11 & 256.3 \\
CPIA & 3.14 & 0.7 & 1 & 5.42 \\
Life expectancy $(\log )$ & 1.33 & 0.49 & 0.09 & 2.22 \\
Life fertility $(\log )$ & 4.11 & 0.17 & 3.33 & 4.37 \\
Democracy & 0.89 & 6.55 & -10 & 10 \\
\hline \hline
\end{tabular}


Appendix D List of countries included in the sample (114)

\begin{tabular}{|c|c|c|}
\hline Albania & India & Swaziland \\
\hline Algeria & Indonesia & Syrian Arab Republic \\
\hline Angola & Iran, Islamic Rep. & Tajikistan \\
\hline Argentina & Jamaica & Tanzania \\
\hline Armenia & Jordan & Thailand \\
\hline Azerbaijan & Kazakhstan & Togo \\
\hline Bangladesh & Kenya & Tonga \\
\hline Belarus & Kyrgyz Republic & Tunisia \\
\hline Belize & Lao PDR & Turkey \\
\hline Benin & Latvia & Uganda \\
\hline Bhutan & Lebanon & Ukraine \\
\hline Bolivia & Lesotho & Uruguay \\
\hline Bosnia and Herzegovina & Liberia & Vanuatu \\
\hline Botswana & Lithuania & Venezuela, RB \\
\hline Brazil & Macedonia, FYR & Vietnam \\
\hline Bulgaria & Madagascar & Yemen, Rep. \\
\hline Burkina Faso & Malawi & Zambia \\
\hline Burundi & Malaysia & Zimbabwe \\
\hline Cambodia & Maldives & \\
\hline Cameroon & Mali & \\
\hline Cape Verde & Mauritania & \\
\hline Central African Republic & Mauritius & \\
\hline Chad & Mexico & \\
\hline Chile & Moldova & \\
\hline Comoros & Mongolia & \\
\hline Congo, Dem. Rep. & Morocco & \\
\hline Congo, Rep. & Mozambique & \\
\hline Costa Rica & Nepal & \\
\hline Cote d'Ivoire & Nicaragua & \\
\hline Djibouti & Niger & \\
\hline Dominica & Pakistan & \\
\hline Dominican Republic & Panama & \\
\hline Ecuador & Papua New Guinea & \\
\hline Egypt, Arab Rep. & Peru & \\
\hline El Salvador & Philippines & \\
\hline Ethiopia & Romania & \\
\hline Fiji & Rwanda & \\
\hline Gabon & Samoa & \\
\hline Gambia, The & Senegal & \\
\hline Georgia & Serbia & \\
\hline Ghana & Seychelles & \\
\hline Grenada & Sierra Leone & \\
\hline Guatemala & Solomon Islands & \\
\hline Guinea & South Africa & \\
\hline Guinea-Bissau & Sri Lanka & \\
\hline Guyana & St. Lucia & \\
\hline Haiti & Vincent and the Grenadines & \\
\hline Honduras & Sudan & \\
\hline
\end{tabular}

Countries in bold never received a joint IMF-WB program in the sample 